\title{
Poly-herbal tablet formulation by design expert tool and in vitro anti-lipase activity
}

\author{
Amruta Balekundri ${ }^{*}$, Amit Shahapuri ${ }^{2}$ and Mrityunjaya Patil ${ }^{2}$
}

\begin{abstract}
Background: Traditional medicine being ethnic is preferred worldwide even in these modern days. Obesity is a lifestyle disorder. Many chemically synthesized medicines are available. Poly-herbal medicines can be one of the safest alternatives with less side effects in treating obese patients.

Results: The in vitro anti-lipase activity was carried out for a different concentration. The formulation of the polyherbal tablets was designed using the Design Expert software. The pre-compression and post-compression studies show that the formulation F6 showed better results of all the formulations designed. Stability study results showed that the poly-herbal tablets were stable throughout the studies.

Conclusion: The results show that F6 is the better formulation based on the tablet evaluation, and all the extracts showed inhibitory activity against pancreatic lipase indicating its active role in the treatment of obesity.
\end{abstract}

Keywords: Poly-herbal tablet, In vitro anti-lipase activity, Design expert tool

\section{Background}

Obesity is a severe as well as chronic disorder which is also an important risk factor for lifestyle-related chronic disease. When an imbalance is caused in the consumption of energy (food) and expenditure of energy leads to the condition called obesity, lack of knowledge regarding the nutritional diet and large consumption of fatty materials leads to their accumulation in the human body. The fats when consumed in excess get stored in the adipose tissue of the body. This accumulation leads further to other chronic diseases and disorders in human beings and acts as the risk factor. Secondary diseases are hypertension, type II diabetes, coronary heart disease, hyperlipidemia, and many more disease and disorder. Obesity is said to be one of the considerable contributors of noncommunicable chronic disease worldwide.

\footnotetext{
* Correspondence: amrutaabc11@gmail.com

'Department of Pharmaceutical Quality Assurance, KLE College of Pharmacy, JNMC Campus Nehru Nagar, Belagavi, Karnataka 590010, India Full list of author information is available at the end of the article
}

The increase in consumption of high-fat food and the modern lifestyle are the most prevailing reasons for obesity. Obesity is becoming a global problem in developed as well as developing countries. According to the WHO (World Health Organization), the prevalence of obesity nearly tripled between 1975 and 2016. In 2016, about $13 \%$ of the world population was found to be obese. In the USA, the obesity prevalence is $26 \%$ which is the highest and 3\% in South East Asia which is the lowest. Three hundred forty million children and adolescents are overweight and obese in 2016 [1, 2]. The key enzyme responsible for hydrolysis of fats is pancreatic lipase (PL) which is found in the GI tract; this enzyme can also be considered as the crucial target in lipid metabolism and absorption [3].

The imbalance of energy expenditure and product remains the primary influencer of obesity; other factors like psychotropic treatment steroid hormones contraceptives protease inhibitors also contribute to weight gain that is drug-induced weight gain. 
Decrease in physical activities of the human being with the past lifestyle is also the cause of obesity. Chemicals such as poly-chlorinated bi-phenols and some alkyl phenols act on the endocrine system as system disruptors and affect the normal function leading to obesity [4].

The time of body intake and the number of meals taken vary from person to person and sometimes community. The time of food intake also plays a key role in the balancing of energy consumption, and these directly influence obesity [5].

The breaking down of the dietary fats and oils is carried out by the enzyme lipase (triacylglycerol acylhydrolases). This enzyme has been synthesized by the higher organisms [6].

The inhibition of pancreatic lipase activity which reduces intestinal absorption is one category of drug, and orlistat is a good example. The appetitesuppressing mechanism is used by other categories of drugs, and the example is sibutramine. Apart from providing anti-obesity, these drugs are responsible for having different side-effects like headache, increase in blood pressure, dry mouth, constipation, and many others.

As the chemically synthesized drugs have many side effects, the demand is towards herbal or natural antiobesity medicine. Many medicinal valued herbs have been studied for anti-obesity activity by preparing extracts of different solvents $[7,8]$.

\section{Methods}

\section{Materials}

Indian elm (Holoptelea intigrifolia), kodo millet (Paspalum scrobiculatam), myrobalan (Terminalia chebula) are collected from the local region of Belagavi (India) located at $15.87^{\circ} \mathrm{N} 74.5^{\circ} \mathrm{E}$ and authenticated at ICMR Belagavi by Dr. Harsha Hegde.

\section{Collection and extraction}

All the raw/crude materials were dried at room temperature for 7 days. The dried raw materials were ground to form a coarse powder. Cold maceration was carried out for the coarse powder using $70 \%$ ethanol. The extract was filtered after $48 \mathrm{~h}$ of cold maceration. Marc was used for further extraction with the Soxhlet apparatus using 95\% ethanol. Filtrates collected from both cold maceration and Soxhlet were combined together. Combined filtrate is then taken from concentration using a rotary evaporator (IKA RV 10) at $40{ }^{\circ} \mathrm{C}$ under reduced pressure. The concentrated extract was from the rotary evaporator and then finally kept on water bath to evaporate the remains of solvents in the extract.

\section{Phyto-chemical investigations}

The phyto-chemical investigation was carried out for all crude drug materials for the identification of different classes.

\section{Physico-chemical investigation \\ Ash value}

Total ash Weigh about $2-5 \mathrm{~g}$ of raw material and then take it into the crucible and keep it at a temperature of about $500{ }^{\circ} \mathrm{C}-600{ }^{\circ} \mathrm{C}$ in the muffle furnace till the raw material forms carbon-free ash, then it is cooled, weigh the ash formed, and calculate using the formula:

Total ash $(\%)=$ [weight of the total ash obtained/weight of the crude drug] $\times 100$

Acid insoluble ash The carbon-free ash obtained is boiled with about $25 \mathrm{ml}$ of hydrochloric acid for about 5 min. The insoluble matter is collected in the crucibles (sintered) with ashless filter paper and then wash with hot water and ignite at $500{ }^{\circ} \mathrm{C}$ till constant weight is obtained and further calculate.

$\%$ Acid insoluble ash $=$ [weight of acid insoluble ash/weight of the crude drug] $\times 100$

Water soluble ash The ash (carbon-free) obtained is boiled with $25 \mathrm{ml}$ of water; then with ashless paper, it is collected in the crucibles (sintered), washed with hot water, and ignited at $500{ }^{\circ} \mathrm{C}$ to obtain constant weight; the crucible is weighed and calculation is done.

$\%$ Water soluble ash $=[$ (weight of total ash - weight of water insoluble ash $) /$ weight of crude drug] $\times 100$

\section{Extractive values}

Alcohol soluble extractives About $4 \mathrm{~g}$ of raw material is added to $25 \mathrm{ml}$ of alcohol in a flask and is kept for $24 \mathrm{~h}$ aside. The solution was filtered and the filtrate is poured in petri plates and kept at $105{ }^{\circ} \mathrm{C}$ for $5-6 \mathrm{~h}$, and finally, the extract is weighed.

\% Alcohol soluble extractive

$=[$ weight of extract $/$ weight of plant material $]$ $\times 100$

Water soluble extractives About $4 \mathrm{~g}$ of raw material is added to $25 \mathrm{ml}$ of water in a flask and is kept for $24 \mathrm{~h}$ aside. The solution was filtered and the filtrate is poured 
in petri plates and kept at $105{ }^{\circ} \mathrm{C}$ for $5-6 \mathrm{~h}$, and finally, the extract is weighed.

\% Water soluble extractive

$$
\begin{aligned}
= & {[\text { weight of extract } / \text { weight of plant material }] } \\
& \times 100
\end{aligned}
$$

Loss on drying (LOD) Weigh about $2 \mathrm{~g}$ of raw material and add it to a porcelain dish and keep it in an oven at a temperature of about $100-105{ }^{\circ} \mathrm{C}$ until a constant weight is gained and then cooled and weighed.

$\operatorname{LOD}($ Loss on drying $)=$ Initial weight of the raw material - Final weight of the raw material

\section{In vitro lipase activity}

The plant extracts were first macerated with phosphate buffer saline $(1 \mathrm{mg} / \mathrm{ml})$ for $4-5 \mathrm{~h}$ at $37{ }^{\circ} \mathrm{C}$, and then the solution is centrifuged at speed of 3500$4000 \mathrm{rpm}$ for $10-15 \mathrm{~min}$. The supernatant is further used as the stock solution, and further working standards are prepared by diluting with the phosphate buffer saline. Standard solution is prepared by dissolving one capsule content of orlistat in $12 \mathrm{ml}$ of dimethylsulphoxide (DMSO) solution. The enzyme solution is prepared by dissolving $6 \mathrm{mg}$ of porcine pancreatic lipase enzyme in $10 \mathrm{ml}$ of the buffer solution (should be prepared and used freshly). Both the standard and the sample (plant extract) are incubated at $37{ }^{\circ} \mathrm{C}$ after adding $50 \mu \mathrm{l}$ of enzyme solution, $25 \mu \mathrm{l}$ of PNPB (8.4 $\mu \mathrm{l}$ of PNPB in $10 \mathrm{ml}$ of acetonitrile) solution, and $100 \mu \mathrm{l}$ of buffer solution. ELISA plate reader is used to determine the lipase activity at 400 $\mathrm{nm}$ and the inhibition percentage was calculated by using the formula:

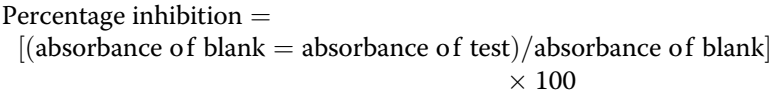

\section{Anti-oxidant activity}

DPPH (2, 2-diphenyl-1-picrylhydrazyl) reagent is used for performing the anti-oxidant activity by UVspectroscopy method. DPPH solution of $0.1 \mathrm{Mm}$ concentration is prepared to water as a solvent. Different concentrations of the sample solutions are prepared from a stock of $1 \mathrm{mg} / \mathrm{ml}$ stock. Ascorbic acid is used as the standard reference substance and the stock solution of $1 \mathrm{mg} / \mathrm{ml}$ is prepared. An equal amount of DPPH is added to an equal amount of both the sample and standard solution separately and allowed to react in a dark environment, and then these solutions are checked for absorbance at $517 \mathrm{~nm}$ under UV- spectroscopy. The process is carried out in triplicate and the average is considered.

(\%)DPPH Scavenging Effect $=$

[(Absorbance of standard - Absorbance of sample)

/Absorbance of standard] $\times 100$

\section{Design expert DoE}

The $3^{2}$ full factorial design was applied to the formulation design of the poly-herbal tablets. The two different factors are evaluated in this design at three different levels. The two independent variables selected are ethyl cellulose (binder) and microcrystalline cellulose (disintegrant). There are three different levels for the selected variables as low, intermediate, and high, and they are coded as $-1,0$, and +1 , respectively. The responses are considered as dependent variables, and they are hardness, friability, and disintegration time of the designed and formulated polyherbal tablets. The software Design Expert 12 (StatEase Minneapolis, MN, USA) was used for the design of the formulation. The total of 9 runs (formulations) were designed (Table 1) and the relationship of the dependent and independent variables was studies by gaining the surface responses, and finally, the significant model was achieved.

1. Independent levels:

Ethyl cellulose(X1)

Microcrystalline cellulose (X2)

2. Dependent levels:

Hardness (Y1)

Friability (Y2)

Disintegration time (Y3)

\begin{tabular}{|c|c|c|c|c|}
\hline \multirow[t]{2}{*}{ Codes } & \multicolumn{2}{|c|}{ Code levels } & \multicolumn{2}{|c|}{ Actual values (mg) } \\
\hline & $\mathrm{X} 1$ & $\mathrm{X} 2$ & $\mathrm{X} 1$ & $\mathrm{X} 2$ \\
\hline F1 & +1 & +1 & 40 & 40 \\
\hline F2 & 0 & -1 & 30 & 20 \\
\hline F3 & -1 & 0 & 20 & 30 \\
\hline F4 & +1 & -1 & 40 & 20 \\
\hline F5 & 0 & 0 & 30 & 30 \\
\hline F6 & -1 & +1 & 20 & 40 \\
\hline F7 & +1 & 0 & 40 & 30 \\
\hline F8 & 0 & +1 & 30 & 40 \\
\hline F9 & -1 & -1 & 20 & 20 \\
\hline
\end{tabular}

Table 1 Levels of independent variables in the tablet design 
Table 2 Formula table

\begin{tabular}{|c|c|c|c|c|c|c|c|c|c|}
\hline Ingredients & F1 & F2 & F3 & F4 & F5 & F6 & F7 & F8 & F9 \\
\hline Indian elm & 100 mg & $100 \mathrm{mg}$ & 100 mg & $100 \mathrm{mg}$ & $100 \mathrm{mg}$ & $100 \mathrm{mg}$ & $100 \mathrm{mg}$ & $100 \mathrm{mg}$ & $100 \mathrm{mg}$ \\
\hline Kodo millet & 100 mg & $100 \mathrm{mg}$ & 100 mg & $100 \mathrm{mg}$ & $100 \mathrm{mg}$ & $100 \mathrm{mg}$ & 100 mg & $100 \mathrm{mg}$ & $100 \mathrm{mg}$ \\
\hline Myrobalan & 100 mg & $100 \mathrm{mg}$ & 100 mg & $100 \mathrm{mg}$ & $100 \mathrm{mg}$ & $100 \mathrm{mg}$ & 100 mg & $100 \mathrm{mg}$ & $100 \mathrm{mg}$ \\
\hline Ethyl cellulose & $40 \mathrm{mg}$ & $30 \mathrm{mg}$ & $20 \mathrm{mg}$ & $40 \mathrm{mg}$ & $30 \mathrm{mg}$ & $20 \mathrm{mg}$ & $40 \mathrm{mg}$ & $30 \mathrm{mg}$ & $20 \mathrm{mg}$ \\
\hline Microcrystalline cellulose & $40 \mathrm{mg}$ & $20 \mathrm{mg}$ & $30 \mathrm{mg}$ & $20 \mathrm{mg}$ & $30 \mathrm{mg}$ & $40 \mathrm{mg}$ & $30 \mathrm{mg}$ & $40 \mathrm{mg}$ & 20 mg \\
\hline Magnesium Stearate & $1 \mathrm{mg}$ & $1 \mathrm{mg}$ & $1 \mathrm{mg}$ & $1 \mathrm{mg}$ & $1 \mathrm{mg}$ & $1 \mathrm{mg}$ & $1 \mathrm{mg}$ & $1 \mathrm{mg}$ & $1 \mathrm{mg}$ \\
\hline Stevia & $8 \mathrm{mg}$ & $8 \mathrm{mg}$ & $8 \mathrm{mg}$ & $8 \mathrm{mg}$ & $8 \mathrm{mg}$ & $8 \mathrm{mg}$ & $8 \mathrm{mg}$ & $8 \mathrm{mg}$ & $8 \mathrm{mg}$ \\
\hline PEG-4000 & $10 \mathrm{mg}$ & $10 \mathrm{mg}$ & $10 \mathrm{mg}$ & $10 \mathrm{mg}$ & $10 \mathrm{mg}$ & $10 \mathrm{mg}$ & $10 \mathrm{mg}$ & $10 \mathrm{mg}$ & $10 \mathrm{mg}$ \\
\hline Dibasic calcium phosphate & $q / s$ & $q / s$ & $q / s$ & $q / s$ & $q / s$ & $q / s$ & $q / s$ & $q / s$ & $q / s$ \\
\hline Total weight & $420 \mathrm{mg}$ & $420 \mathrm{mg}$ & $420 \mathrm{mg}$ & $420 \mathrm{mg}$ & $420 \mathrm{mg}$ & $420 \mathrm{mg}$ & $420 \mathrm{mg}$ & $420 \mathrm{mg}$ & $420 \mathrm{mg}$ \\
\hline
\end{tabular}

\section{Tablet formulation}

Pre-compression studies

Angle of repose The angle of repose study was carried out for the powder by the funnel method. Blend of powder was taken and poured using the funnel to form a heap of the blend. The funnel was adjusted so that the tip of the cone heap just touches the lower tip of the funnel. The base diameter of the blend heap and the height of the heap were measured and the same was carried out three times, and the average diameter was calculated. Further, the angle of repose was calculated using the formula:

$\operatorname{Tan} \theta=$ height of the cone formed by powder /radius of the cone formed by powder

Loose bulk density The bulk density of the powder is measured by filling the graduated cylinder with the powder of known quantity. The volume of the graduated cylinder is measured and density is calculated by using formula:

\section{Bulk Density $=$ mass of powder}

/volume of the powder in graduated cylinder

Tapped bulk density Density tester apparatus is used to carry out the tapped density parameter. The known mass of powder is filled in the graduated cylinder of the density tester and then fixed to the apparatus. The testing apparatus is tapped from a specific height of $14 \mathrm{~mm}$ and another $3 \mathrm{~mm}$ on the surface of the density tester for 100 taps or until a constant volume is measured, and then tapped density is calculated by:

Tapped Density $=$ mass of powder taken

/final volume of powder obtained after tapping process
Carr's compressibility index The compressibility is calculated by using the results obtained from bulk density and tapped density and then substituting them in the formula:

$$
\text { Carr's Compressibility Index }=100\left(V_{i}-V_{f}\right) / V_{i}
$$

where $V_{i}=$ initial volume of the powder before tapping process and $V_{f}=$ final volume of the powder after tapping process.

Hausner ratio Hausner ratio is the value obtained from the initial volume of the powder to that of the final volume of the powder after the tapping process.

$$
\text { Hausner ratio }=\mathrm{V}_{\mathrm{o}} / \mathrm{V}_{\mathrm{f}}
$$

where $V_{0}=$ unsettled apparent volume of the powder and $V_{f}=$ final volume of powder after tapping.

\section{Formulation of tablets}

The plant extracts and the excipients are weighed in accordance to the formula designed by the help of the DoE software, and the formula is shown in Table 2. The ingredients are mixed properly and sieved to obtain uniform mixture of the ingredients. The mixture is then

Table 3 Phytochemical investigation data

\begin{tabular}{llll}
\hline Test & Indian elm & Kodo millet & Myrobalan \\
\hline Alkaloids & + & + & - \\
Carbohydrates & - & + & - \\
Flavonoids & + & - & - \\
Tannins & + & + & + \\
Steroids & - & - & - \\
\hline
\end{tabular}


Table 4 Physico-chemical investigation of extract

\begin{tabular}{llll}
\hline Parameters & Indian elm & Kodo millet & Myrobalan \\
\hline Lod (loss on drying)/moisture content & $28 \%$ & $22 \%$ & $23 \%$ \\
Total ash & $11 \%$ & $2.5 \%$ & $2.5 \%$ \\
Acid insoluble ash value & $2 \%$ & $1 \%$ & $1 \%$ \\
Water soluble ash value & $1.5 \%$ & $1.5 \%$ & $1.5 \%$ \\
Alcohol soluble extract & $7.5 \%$ & $10.75 \%$ & $17.7 \%$ \\
Water soluble extract & $37.5 \%$ & $13.25 \%$ & $19.5 \%$ \\
\hline
\end{tabular}

taken to tablet press, and the tablets are formed by direct compression technique.

\section{Post-compression studies}

All the post-compression study triplicates were recorded, and the average was considered as the final record.

Hardness The hardness of the tablets is measured using the Monsanto hardness tester, and the hardness of the tablets is recorded in $\mathrm{kg} / \mathrm{cm}^{2}$ unit.

Thickness The thickness of the tablets is measured using vernier calipers, and the thickness is recorded in mm unit.

Diameter Diameter is measured in $\mathrm{mm}$ unit by using the vernier calipers, and the data is recorded.

Friability Roche friability tester is used for performing the friability studies of the tablets. Twenty tablets from each batch are taken and weighed together and recorded as the initial weight of the tablets. Then the tablets are loaded in the apparatus and the apparatus is rotated for $4 \mathrm{~min}$ that is 100 rotations $(25 \mathrm{rpm})$. Finally, the tablets are removed and de-dusted. The de-dusted tablets are weighed and recorded as final weight, and friability is calculated by:

Percentage of Friability

$=($ Initial weight - final weight $) /$ Initial weight $\times 100$

Weight variation For studying the weight variations in the tablet formulation, twenty tablets were taken from each bath and weighed individually and the weight was noted. The average weight of the tablets was calculated and then further substituted in the formula

Weight variation = individual weight of the tablet/ average weight of the tablets $\times 100$

Disintegration The disintegration of the tablets was carried out using the disintegration apparatus, $900 \mathrm{ml}$ of distilled water is added to the disintegration vessel, and six tablets from each batch are taken and loaded in the apparatus. The temperature is maintained at $37 \pm 2{ }^{\circ} \mathrm{C}$. And 28-32 cycles per minutes frequency is adjusted, and the time taken for the tablets to disintegrate is recorded and the time taken must not be more than 15 min for the conventional tablets.

\section{Accelerated stability testing}

The stability of the formulated poly-herbal tablets is carried out for the period of 30 days at $25{ }^{\circ} \mathrm{C} \pm 2{ }^{\circ} \mathrm{C} / \mathrm{RH} 60$ $\pm 5 \%$ (room temperature) and $40{ }^{\circ} \mathrm{C} \pm 2{ }^{\circ} \mathrm{C} / \mathrm{RH} 75 \pm 5 \%$ (accelerated temperature); the evaluation is performed on the 7 th, 15 th, and 30th days.

\section{Results}

Phyto-chemical investigation results

Phyto-chemical investigation results are shown in Table 3.

\section{Results of Physico-chemical investigation}

Results of Physico-chemical investigation are shown in Table 4.

\section{Results of in vitro anti-lipase activity}

Results of in vitro anti-lipase activity are shown in Table 5 and Fig. 1.

Table 5 In vitro lipase activity results

\begin{tabular}{lllllll}
\hline Concentration $(\boldsymbol{\mu g} / \mathbf{m l})$ & $\mathbf{1 0}$ & $\mathbf{2 0}$ & $\mathbf{4 0}$ & $\mathbf{8 0}$ & $\mathbf{1 6 0}$ & $\mathbf{3 2 0}$ \\
\hline Orlistat & 2.249489 & 103.8855 & 284.6626 & 489.7751 & 497.955 & 565.2352 \\
Formulation & 7.770961 & 98.77301 & 185.2761 & 393.2515 & 492.0245 & 520.2454 \\
Indian elm (HI) & 32.92434 & 50.30675 & 148.8753 & 363.3947 & 400 & 497.7505 \\
Kodo millet (PS) & 37.01431 & 103.8855 & 179.1411 & 233.5378 & 401.0225 & 492.0245 \\
Myrobalan (TC) & 30.87935 & 81.39059 & 135.5828 & 211.8609 & 424.3354 & 496.319 \\
\hline
\end{tabular}




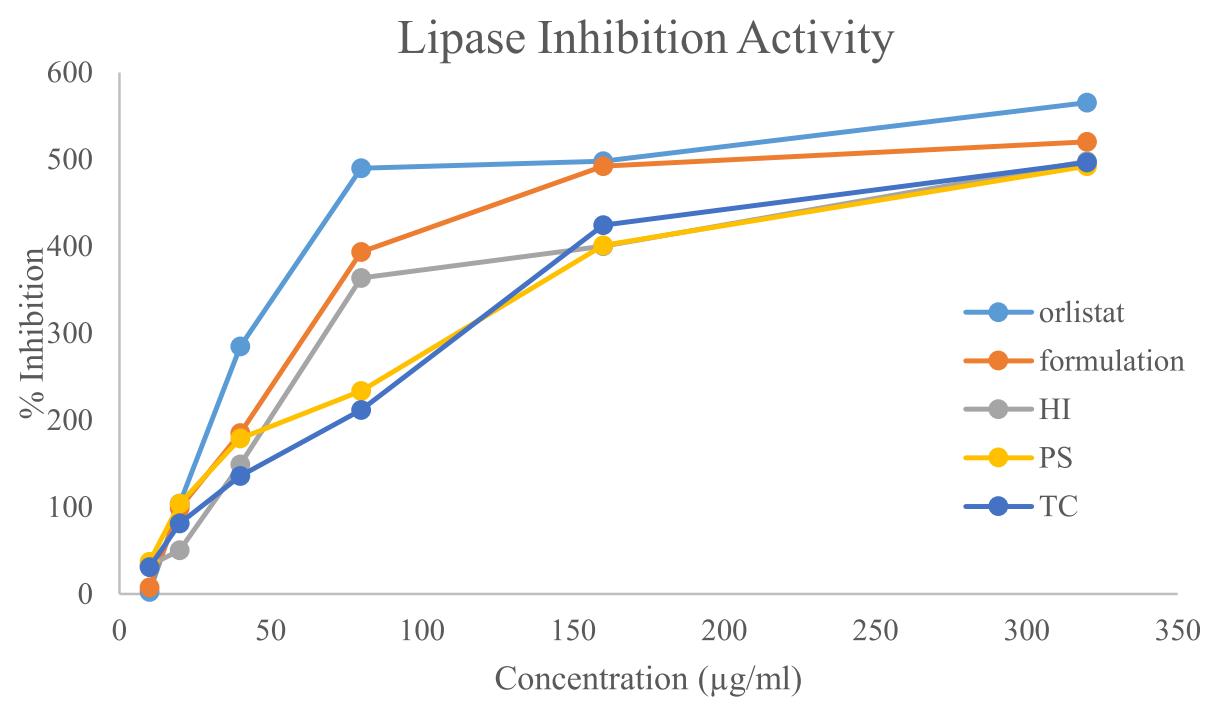

Fig. 1 In vitro lipase inhibition activity data

Results of anti-oxidant activity

Results of anti-oxidant activity are shown in Fig. 2.

\section{Results of formulation}

\section{Pre-compression results}

Pre-compression results are shown in Table 6.

\section{Post-compression results}

Post-compression results are shown in Table 7.

\section{Surface responses of DoE}

Surface responses of DoE are shown in Table 8 and Figs. 3, 4, and 5 .

The overlay plot (Fig. 6) has two colors which differentiate the runs/trails of formulation into the criteria of the dependent variables. The yellow color shows the region which satisfies the criteria whereas the grey region shows the unsatisfied region. The best results are obtained by the formulation F6 and is considered as the optimized one.

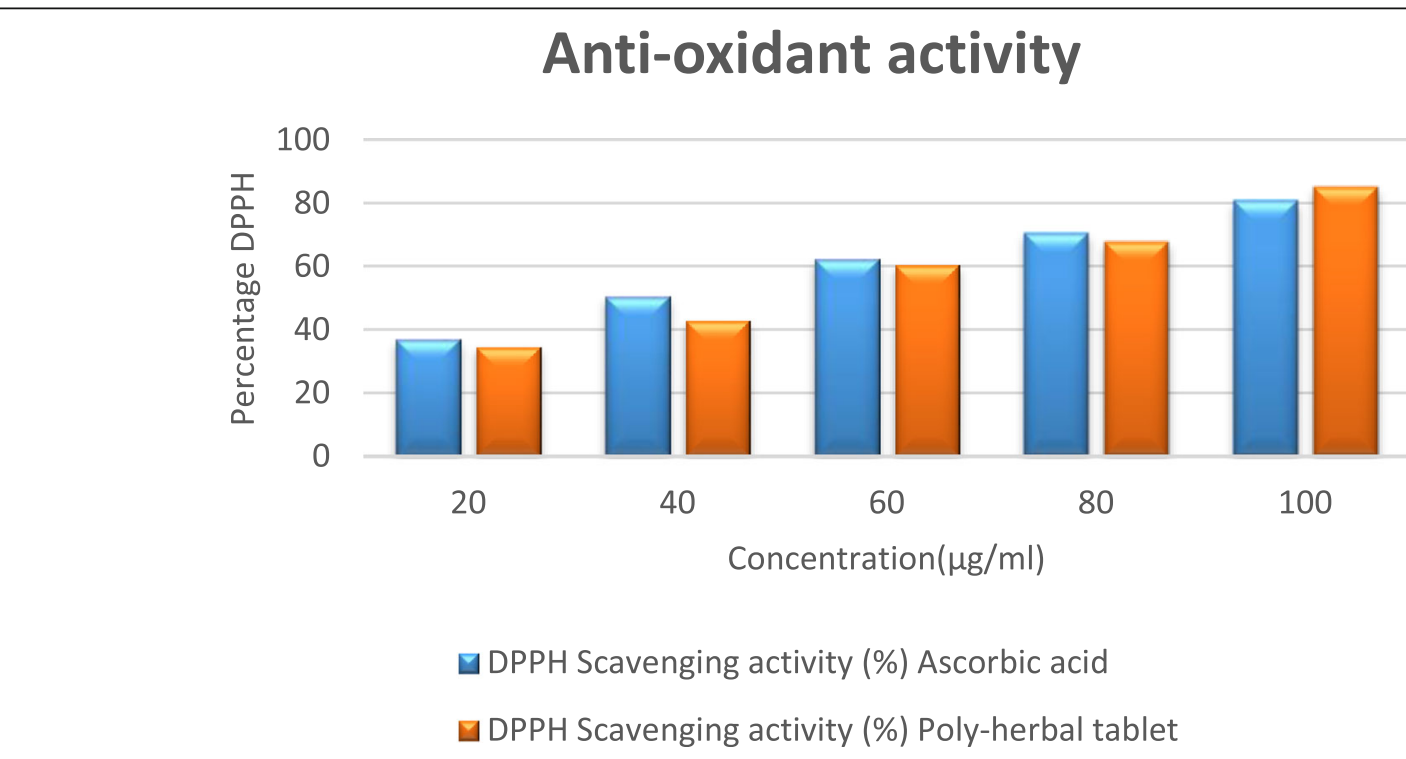

Fig. 2 DPPH scavenging activity data 
Table 6 Pre-compression study data

\begin{tabular}{|c|c|c|c|c|c|}
\hline Formulation & Angle of repose $\left(^{\circ}\right)$ & Loose bulk density $\left(\mathrm{g} / \mathrm{cm}^{3}\right)$ & Tapped bulk density $\left(\mathrm{g} / \mathrm{cm}^{3}\right)$ & Carr's Compressibility Index & Hausner ratio \\
\hline F1 & $32.52 \pm 0.5321$ & $0.5712 \pm 0.0063$ & $0.6614 \pm 0.006107$ & $13.63 \pm 0.7156$ & $1.157 \pm 0.0095$ \\
\hline F2 & $34.21 \pm 0.2264$ & $0.5626 \pm 0.0050$ & $0.6724 \pm 0.002302$ & $16.32 \pm 0.8488$ & $1.195 \pm 0.0120$ \\
\hline F3 & $31.13 \pm 0.1846$ & $0.5724 \pm 0.0252$ & $0.6768 \pm 0.027289$ & $15.43 \pm 0.7505$ & $1.182 \pm 0.0104$ \\
\hline F4 & $32.42 \pm 0.3523$ & $0.5774 \pm 0.0141$ & $0.6846 \pm 0.010502$ & $15.66 \pm 0.8256$ & $1.185 \pm 0.0116$ \\
\hline F5 & $35.43 \pm 0.2906$ & $0.5594 \pm 0.0038$ & $0.6522 \pm 0.001924$ & $14.22 \pm 0.5965$ & $1.165 \pm 0.0080$ \\
\hline F6 & $34.67 \pm 0.2776$ & $0.567 \pm 0.0040$ & $0.6528 \pm 0.00249$ & $13.14 \pm 0.8698$ & $1.151 \pm 0.0114$ \\
\hline F7 & $33.01 \pm 0.2197$ & $0.5444 \pm 0.0032$ & $0.633 \pm 0.002121$ & $13.99 \pm 0.4103$ & $1.162 \pm 0.0055$ \\
\hline F8 & $32.92 \pm 0.406362$ & $0.5518 \pm 0.0121$ & $0.6526 \pm 0.01506$ & $15.44 \pm 0.1561$ & $1.182 \pm 0.0021$ \\
\hline F9 & $32.45 \pm 0.9388$ & $0.55 \pm 0.0131$ & $0.6506 \pm 0.011929$ & $14.11 \pm 0.6118$ & $1.164 \pm 0.0083$ \\
\hline
\end{tabular}

\section{Accelerated stability testing}

Accelerated stability testing is shown in Table 9.

\section{Discussion}

\section{Phytochemical investigations}

The pre-formulation studies start with the phytochemical investigations. In the phytochemical investigation, all the three extracts were tested for phytochemical presence. Qualitative screening of phytochemicals is carried out separately for the three extracts. Qualitative screening of major classes like alkaloids, carbohydrates, flavonoids, tannins, and steroids is carried out. The results of these phytochemical tests revealed the presence of alkaloids, tannins, and flavonoids in the extract of Indian elm; presence of alkaloids, tannins, and carbohydrates in the extract of kodo millet; and the presence of tannins in the extract of myrobalan. The results of phytochemical investigations are shown in Table 3 .

\section{Physicochemical investigations}

The physicochemical investigation is one of the important investigation test in the pre formulation area of the herbs and extracts. The parameters carried out under the physicochemical investigations were loss on drying (LOD), ash values (total ash, acid insoluble ash value, water soluble ash value), and extractive values (alcohol soluble extract, water soluble extract). The extracts are treated separately for the physicochemical investigations. The results are presented in Table 4.The highest percentage of loss on drying (LOD) was shown by Indian elm (28\%) followed by myrobalan (23\%) and kodo millet (22\%). The result of total ash value parameter was shown highest by Indian elm (11\%), kodo millet $(2.5 \%)$, and myrobalan $(2.5 \%)$. In case of acid insoluble ash value parameter Indian elm (2\%), kodo millet (1\%), and myrobalan (1\%), where as in the case of water insoluble ash value parameter Indian elm, kodo millet, and myrobalan, all showed up the same percentage value that is $1.5 \%$. Extractive value parameter was carried out as alcohol soluble extract and water soluble extract. Indian elm showed the lowest alcohol soluble extractive value (7.5\%), kodo millet (10.75\%), and myrobalan (17.7\%). In water soluble extractive value, kodo millet is the lowest value $(13.5 \%)$ whereas myrobalan showed $19.5 \%$ and Indian elm $37.5 \%$.

Table 7 Post-compression study data

\begin{tabular}{lllllll}
\hline Formulation & Hardness $\left(\mathbf{k g} / \mathbf{c m}^{\mathbf{2}}\right)$ & Thickness $(\mathbf{m m})$ & Diameter $(\mathbf{m m})$ & Friability $(\%)$ & Weight variation (\%) & Disintegration $(\mathbf{m i n})$ \\
\hline F1 & $2.21 \pm 0.0849$ & $3.021 \pm 0.011$ & $11.00 \pm 0.0082$ & $0.65 \pm 0.0230$ & $417.9 \pm 3.4777$ & $16.01 \pm 0.4070$ \\
F2 & $2.56 \pm 0.0334$ & $3.02 \pm 0.012$ & $11.00 \pm 0.0085$ & $0.56 \pm 0.015$ & $420.35 \pm 3.8289$ & $15.28 \pm 0.2306$ \\
F3 & $2.77 \pm 0.0567$ & $3.01 \pm 0.013$ & $11.004 \pm 0.0069$ & $0.61 \pm 0.01$ & $421.5 \pm 3.9934$ & $16.39 \pm 0.2393$ \\
F4 & $2.04 \pm 0.0516$ & $3.01 \pm 0.012$ & $11.003 \pm 0.0082$ & $0.57 \pm 0.005$ & $421.75 \pm 2.7120$ & $14.32 \pm 0.2884$ \\
F5 & $2.87 \pm 0.078$ & $3.02 \pm 0.006$ & $11.002 \pm 0.0078$ & $0.59 \pm 0.005$ & $420.1 \pm 3.3701$ & $15.33 \pm 0.1981$ \\
F6 & $3.515 \pm 0.022$ & $3.02 \pm 0.091$ & $11 \pm 0.00471$ & $0.52 \pm 0.001$ & $421 \pm 2.67542$ & $13.05 \pm 0.2744$ \\
F7 & $2.28 \pm 0.04714$ & $3.02 \pm 0.0074$ & $11.006 \pm 0.00069$ & $0.62 \pm 0.005$ & $420.65 \pm 2.1343$ & $14.26 \pm 0.2331$ \\
F8 & $2.47 \pm 0.0948$ & $3.02 \pm 0.0084$ & $11.002 \pm 0.0091$ & $0.58 \pm 0.004$ & $422.3 \pm 3.5108$ & $15.14 \pm 0.1615$ \\
F9 & $2.56 \pm 0.0948$ & $3.01 \pm 0.0103$ & $11.007 \pm 0.0082$ & $0.64 \pm 0.017$ & $423.1 \pm 2.9181$ & $17.27 \pm 0.1860$ \\
\hline
\end{tabular}


Table 8 Responses

\begin{tabular}{lllllll}
\hline Response & Sum of squares & df & Mean square & $\boldsymbol{p}$ value & $\boldsymbol{R}^{\mathbf{2}}$ & Model \\
\hline Y1 & 1.07 & 2 & 0.5359 & 0.0263 & 0.7026 & Significant \\
Y2 & 0.0109 & 3 & 0.0036 & 0.0336 & 0.8002 & Significant \\
Y3 & 10.67 & 3 & 3.59 & 0.0188 & 0.8429 & Significant \\
\hline
\end{tabular}

\section{In vitro lipase activity}

In vitro lipase activity was carried out for all the three extracts separately as well as the formulation and compared with the standard orlistat. Increasing concentration from $10-320 \mu \mathrm{g} / \mathrm{ml}$ were taken to carry out the in vitro lipase activity. Collective results of the in vitro lipase activity are presented in the Table 5 and the graph of the activity in Fig. 1. From concentration level 10, 20, and $40 \mu \mathrm{g} / \mathrm{ml}$, kodo millet showed up the higher response when the in vitro lipase activity was conducted and the response was $37.01431 \quad(10 \mu \mathrm{g} / \mathrm{ml})$, $103.8855(20 \mu \mathrm{g} / \mathrm{ml})$, and $179.1411(40 \mu \mathrm{g} / \mathrm{ml})$. At level $80 \mu \mathrm{g} / \mathrm{ml}$ (363.39), Indian elm had the highest response when compared to other extracts. At level $160 \mu \mathrm{g} / \mathrm{ml}$ (424.33), myrobalan showed up the highest, where in at level $320 \mu \mathrm{g} / \mathrm{ml}$, the highest as well as similar response was shown up by both myrobalan (496.314) and Indian elm (497.750). In case of formulations, there was an increase in response with increase in the concentration of the extract mixtures, so the combination of the extract was preferred [9-11].

\section{Anti-oxidant activity}

DPPH scavenging activity of the formulation was carried out with ascorbic acid as the reference standard. Concentration range $20-100 \mu \mathrm{g} / \mathrm{ml}$ was selected, and the solutions of both sample and standard used were prepared freshly. The response of the activity showed there was an increase in response with increase in concentration in the selected range. The results are shown in Fig. 2.

\section{Pre-compression parameters}

In the formulation of the poly-herbal tablets, the precompression parameters performed were angle of repose $(\theta)$, loose bulk density $\left(\mathrm{g} / \mathrm{cm}^{3}\right)$, tapped bulk density (g/cm3), Carr's Compressibility Index, and Hausner ratio. For the better compression of the tablet, it is important that the pre-compression parameters show a better response. The response reveals the flow properties, moisture content, and compressing properties. Data of the pre-compression parameter is presented in Table 6.

\section{Post-compression parameters}

Post compression parameters are the quality control aspect of the compressed tablet. Variation in the ratio of binder and disintegrant is responsible for the variation in response of hardness, friability, and disintegrations. The other quality control parameters reported are thickness, diameter, and weight variation. Collective results of post-compression are shown in Table 7.
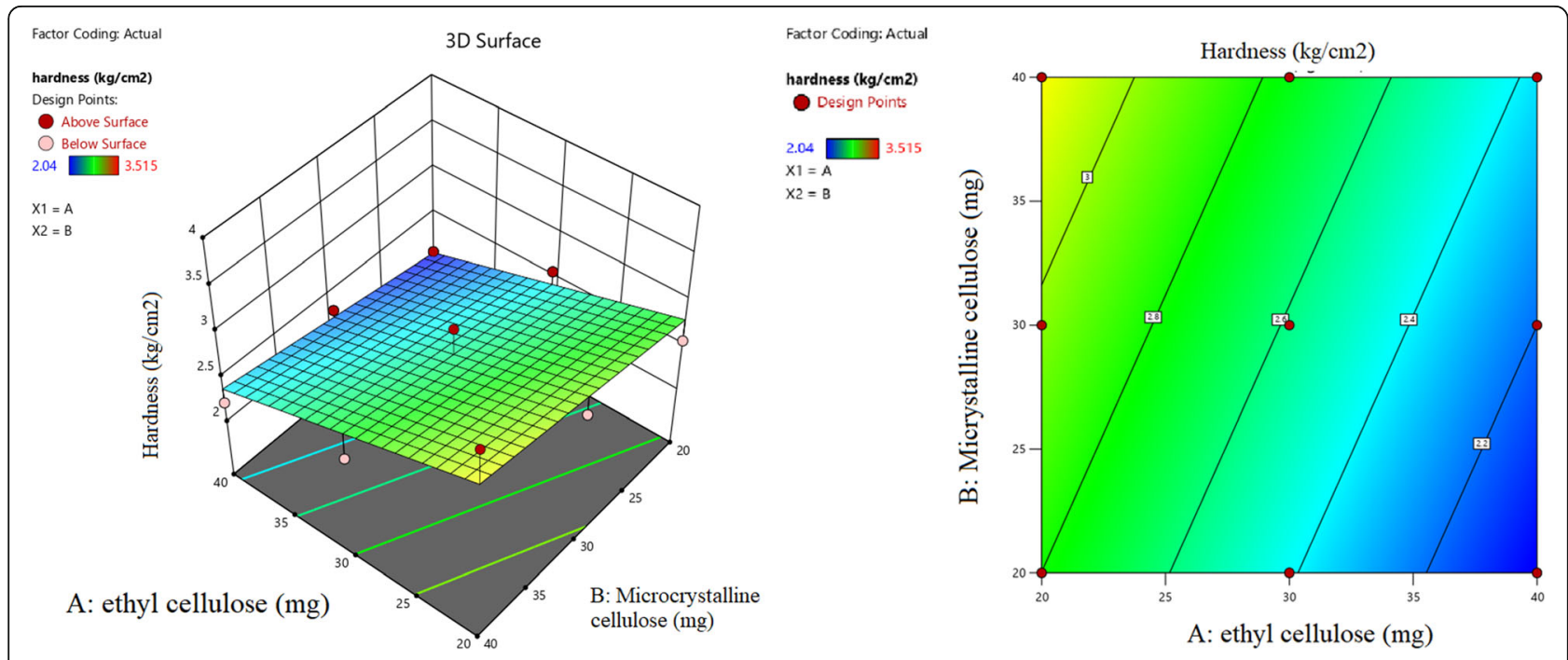

Fig. 3 Hardness responses 

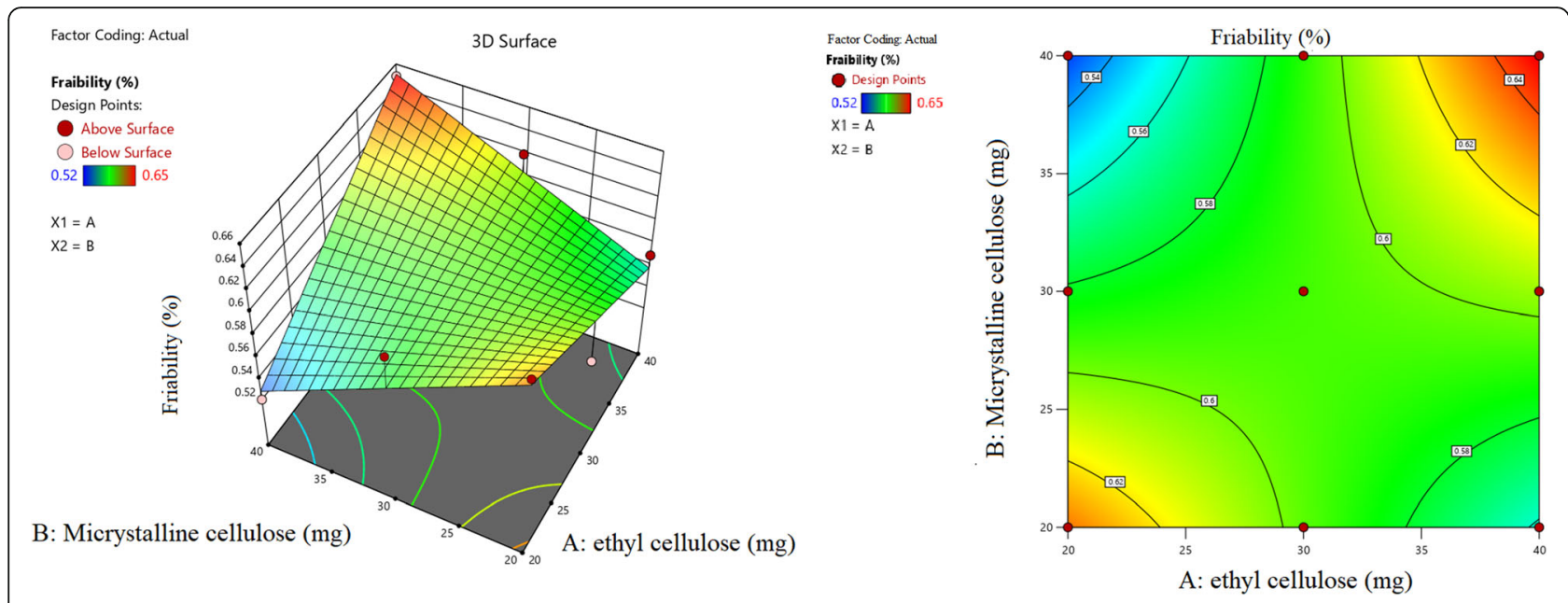

Fig. 4 Friability responses

\section{Design expert (DoE)}

The Design Expert 12 software is used in the present study for the formulation design. The $3^{2}$ factorial design is applied where two independent variables are selected, binder (ethyl cellulose) and disintegrant (Microcrystalline cellulose), which have three different levels, low $(-1)$, intermediate, (0) and high $(+1)$, which are considered. Based on this variables, nine different formulations are designed with varying ratios of the binder and disintegrant. The results obtained by conducting evaluation parameters of tablets are added to the software DoE for obtaining the results for model significance. The responses are recorded in the form of hardness, friability, and disintegrant for all the nine formulations .The response data is shown in the Table 8 and response surfaces are shown for hardness (Fig. 3), friability (Fig. 4), and disintegration time (Fig. 5). Increase in binder will increase the hardness and decrease in the friability and disintegration time will increase. Increase in the concentration of disintegrant will reduce the disintegration time and decrease the hardness level. Hence, the optimum ratio of the binder and disintegrant is require. The formulation F6 shows the optimum ratio. The DoE surface response of all $\mathrm{Y} 1, \mathrm{Y} 2$, and $\mathrm{Y} 3$ showed that the model was significant as the $p$ value was less than $0.05 \%$ and the overlay plot of the trails shows that formulation F6 satisfies all the criteria better among all the nine formulations and is further considered for optimization [12-14].

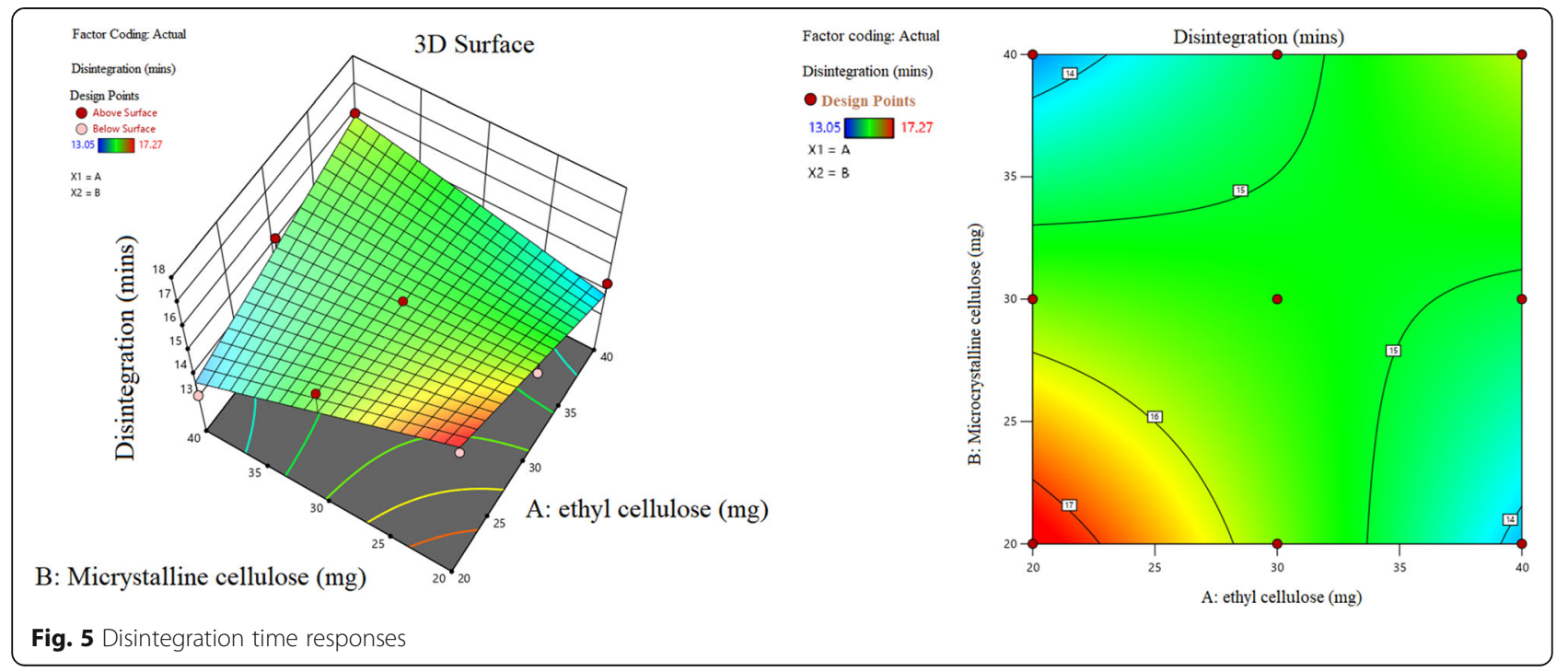




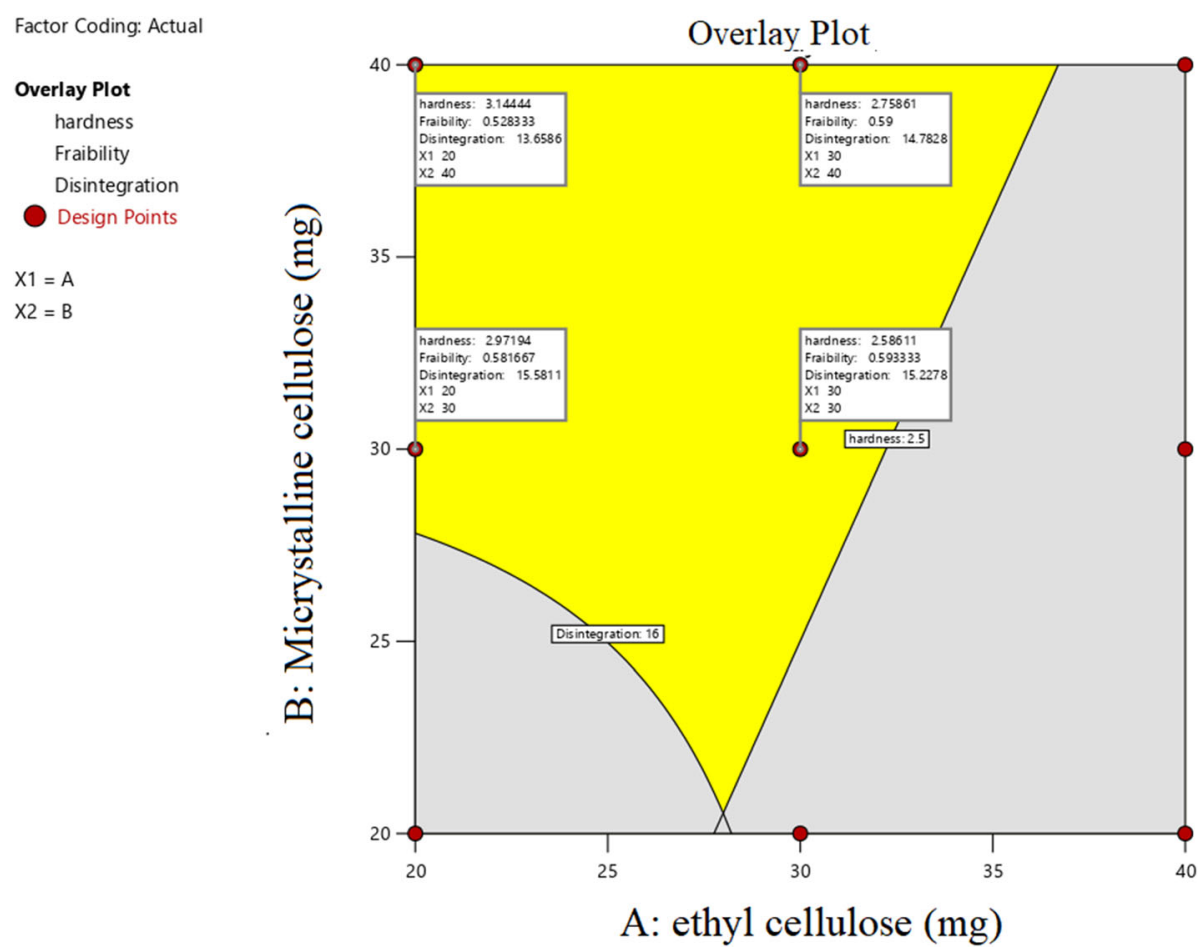

Fig. 6 Overlay plot

\section{Accelerated stability testing}

The stability study was conducted for formulation F6 for duration of 30 days at two different conditions, one at room temperature $\left(25{ }^{\circ} \mathrm{C} \pm 2{ }^{\circ} \mathrm{C} / \mathrm{RH} 60 \pm 5 \%\right)$ and accelerated temperature $\left(40{ }^{\circ} \mathrm{C} \pm 2{ }^{\circ} \mathrm{C} / \mathrm{RH} 75 \pm 5 \%\right)$, and the results (Table 9) showed that the poly-herbal tablets were stable [15].

\section{Conclusion}

The phyto-chemical investigation and the phyiscochemical were carried out prior to the poly-herbal tablet formulation. The in vitro anti-lipase activity was carried out for a different concentration. The $3^{2}$ factorial design was applied by using the design of experiment software, and the 9 different formulations were prepared with variation in disintegrating agent and binding agent ratios. The formulation F6 with (20:40 ratio) showed better results of the evaluation parameters conducted. The formulation F6 was considered the better one and stability studies were conducted with showed good stability results. Although the extracts showed up to have the inhibitory activity against the pancreatic enzymes in the in vitro study, but it cannot be considered effective on human beings until the pre-clinical and clinical studies are carried out which are required to prove the efficiency of the extracts. Results of the in vitro study can be considered as the background highlights for the future investigations of the herbal extracts which can be developed to the medicinal value ingredient for treatment and prevention of obesity and related metabolic diseases.

Table 9 Accelerated stability study data

\begin{tabular}{|c|c|c|c|c|c|c|c|}
\hline \multirow[t]{3}{*}{ Parameters } & \multirow[t]{3}{*}{ Initial } & \multicolumn{3}{|c|}{ Room temperature } & \multicolumn{3}{|c|}{ Accelerated temperature } \\
\hline & & \multicolumn{3}{|c|}{$25^{\circ} \mathrm{C} \pm 2{ }^{\circ} \mathrm{C} / \mathrm{RH} 60 \pm 5 \%$} & \multicolumn{3}{|c|}{$40^{\circ} \mathrm{C} \pm 2{ }^{\circ} \mathrm{C} / \mathrm{RH} 75 \pm 5 \%$} \\
\hline & & 7th day & 15th day & 30 th day & 7th day & 15th day & 30th day \\
\hline Hardness $\left(\mathrm{kg} / \mathrm{cm}^{2}\right)$ & 3.51 & 3.51 & 3.55 & 3.53 & 3.50 & 3.49 & 3.48 \\
\hline Friability (\%) & 0.52 & 0.52 & 0.51 & 0.52 & 0.52 & 0.53 & 0.51 \\
\hline Disintegration (min) & 13.05 & 13.05 & 13.06 & 13.06 & 13.10 & 13.16 & 13.09 \\
\hline
\end{tabular}




\section{Abbreviations}

WHO: World Health Organization; PL: Pancreatic lipase; LOD: Loss on drying: DMSO: Dimethylsulphoxide; PNPB: 4-Nitrophenyl butyrate; DPPH: (2, 2diphenyl-1-picrylhydrazyl); PEG: Polyethylene glycol; DoE: Design of experiments

\section{Acknowledgements}

The authors kindly acknowledge KLE College of Pharmacy Belagavi for the support.

\section{Authors' contributions}

$A B$ has done designed the formulations and carried out the formulation procedures of poly-herbal tablet as well as the pre-compression and postcompression studies along with the stability studies. AS has carried out the collection, extraction, and the in vitro activity. MP has designed the concept, corrections, and drafting of the manuscript. The authors have read and approved the manuscript.

\section{Funding}

No funding was received

\section{Availability of data and materials}

All data and material are available upon request.

Ethics approval and consent to participate

Not applicable

\section{Consent for publication}

Not applicable

\section{Competing interests}

No competing interests to declare.

\section{Author details}

${ }^{1}$ Department of Pharmaceutical Quality Assurance, KLE College of Pharmacy, JNMC Campus Nehru Nagar, Belagavi, Karnataka 590010, India. ²Department of Pharmacognosy, KLE College of Pharmacy, Belagavi, Karnataka 590010, India.

Received: 4 June 2020 Accepted: 21 October 2020

Published online: 17 December 2020

\section{References}

1. Mopuri R, Islam MS (2017) Medicinal plants and phytochemicals with antiobesogenic potentials: a review. Biomed Pharmacother 89:1442-1452. https://doi.org/10.1016/j.biopha.2017.02.108

2. World Health Organization fact sheets details on obesity and overweight; https://www.who.int/news-room/fact-sheets/detail/obesity-and-overweight Access date 15 Sepetember 2020.

3. Hou XD, Ge GB, Weng ZM, Dai ZR, Leng $Y H$, Ding $L L$, Jin $L L$, $Y u Y$, Cao YF, Hou J (2018) Natural constituents from cortex Mori Radicis as new pancreatic lipase inhibitors. Bioorg Chem 80:577-584. https://doi.org/10. 1016/j.bioorg.2018.07.011

4. Wright SM, Aronne $\amalg$ (2012) Causes of obesity. Abdominal Radiol 37(5): 730-732. https://doi.org/10.1007/s00261-012-9862-x

5. Garaulet M, Gómez-Abellán P (2014) Timing of food intake and obesity: a novel association. Physiol Behav 134:44-50. https://doi.org/10.1016/j. physbeh.2014.01.001

6. Rahman HA, Sahib NG, Saari N, Abas F, Ismail A, Mumtaz MW, Hamid AA (2017) Anti-obesity effect of ethanolic extract from Cosmos caudatus Kunth leaf in lean rats fed a high fat diet. BMC Complement Altern Med 17(1):122. https://doi.org/10.1186/s12906-017-1640-4

7. Kim GW, Lin JE, Blomain ES, Waldman SA (2014) Antiobesity pharmacotherapy: new drugs and emerging targets. Clin Pharmacol Therapeutics 95(1):53-66. https://doi.org/10.1038/clpt.2013.204

8. Omar SM, AbdAlla Fl, Abdelgawad NM (2018) Preparation and optimization of fast-disintegrating tablet containing naratriptan hydrochloride using Doptimal mixture design. AAPS PharmSciTech 19(6):2472-2487. https://doi. org/10.1208/s12249-018-1110-4

9. Roh C, Jung U (2012) Screening of crude plant extracts with anti-obesity activity. Int J Mol Sci 13(2):1710-1719. https://doi.org/10.3390/ijms13021710
10. Zheng CD, Duan YQ, Gao JM, Ruan ZG (2010) Screening for anti-lipase properties of 37 traditional Chinese medicinal herbs. J Chin Med Assoc 73(6):319-324. https://doi.org/10.1016/S1726-4901(10)70068-X

11. Kim YS, Lee YM, Kim H, Kim J, Jang DS, Kim JH, Kim JS (2010) Anti-obesity effect of Morus bombycis root extract: anti-lipase activity and lipolytic effect. J Ethnopharmacol 130(3):621-624. https://doi.org/10.1016/j.jep.2010.05.053

12. Fukuda IM, Pinto CF, Moreira CD, Saviano AM, Lourenço FR (2018) Design of Experiments (DoE) applied to pharmaceutical and analytical quality by design (QbD). Braz J Pharm Sci 54(SPE). https://doi.org/10.1590/s217597902018000001006

13. Usman S, Ejaz RR, Safdar KA (2018) Formulation development and optimization of orally disintegrating tablets of montelukast sodium by design-expert. Trop J Pharm Res 17(9):1701-1709. https://doi.org/10.4314/ tjpr.v17i9.3

14. Sammour OA, Hammad MA, Zidan AS, Mowafy AG (2011) QbD approach of rapid disintegrating tablets incorporating indomethacin solid dispersion. Pharm Dev Technol 16(3):219-227. https://doi.org/10.3109/ 10837451003592209

15. ICH Q1A. Guidance for industry: stability testing of new drug substances and products. (R2) 2003. Available from: https://www.fda.gov/downloads/ drugs

\section{Publisher's Note}

Springer Nature remains neutral with regard to jurisdictional claims in published maps and institutional affiliations.

\section{Submit your manuscript to a SpringerOpen ${ }^{\circ}$ journal and benefit from:}

- Convenient online submission

- Rigorous peer review

- Open access: articles freely available online

- High visibility within the field

- Retaining the copyright to your article

Submit your next manuscript at $\boldsymbol{\nabla}$ springeropen.com 